\title{
INTERNALISASI KARAKTER NASIONALISME DALAM KEDIVERSITASAN ETNIS DI SEKOLAH DASAR ISLAM
}

\author{
Retno Wihyanti \\ Universitas Negeri Surakarta, Jawa Tengah, Indonesia \\ retnowihyanti@student.uns.ac.id. \\ Slamet Subiyantoro \\ Universitas Negeri Surakarta, Jawa Tengah, Indonesia \\ s.biyantoro@yahoo.co.id \\ Siti Sutarmi Fadhilah \\ Universitas Negeri Surakarta, Jawa Tengah, Indonesia \\ sitisfadhilah@staff.uns.ac.id
}

\begin{abstract}
INTERNALIZATION OF NATIONALIST CHARACTER ON ETHNIC DIVERSITY IN ISLAMIC ELEMENTARY SCHOOL. The purpose of this study was to explore the meaning of nationalist attitudes in the Islamic manifestations among students with different ethnicities in Islamic elementary schools. The school researched was Diponegoro Islamic Elementary School, Surakarta City. The students are mostly from Arabic ethnic, while the others are minority such as Javanese and Madurese. This study used qualitative method. Data were collected using observation, indepth interviews, and literature review. The observation technique used was passive participation. The literature data collected were national and international journals. Data analysis was done by triangulation. The results showed that the diverse ethnic cultural conditions in Diponegoro Islamic Elementary School provide challenges as well as opportunities for the school to instill nationalism and character of Islamiyah and the
\end{abstract}


diversity gives basic nationalism because Islamic principles are embedded in the vision and mission of the school.

Keywords: character education, elementary school, islamic education, multiethnic, nationalism.

\begin{abstract}
Abstrak
Tujuan penelitian ini adalah untuk menggali pemaknaan sikap nasionalis dalam perwujudan islami di antara siswa-siswa yang memiliki etnis berbeda di sekolah dasar berbasis agama islam. Sekolah yang digunakan sebagai tempat penelitian adalah Sekolah Dasar Islam Diponegoro, Kota Surakarta. Siswa di sekolah tersebut mayoritas merupakan keturunan etnis Arab, sedangkan sisanya adalah etnis minoritas seperti Jawa dan Madura. Penelitian ini menggunakan metode kualitatif. Data dikumpulkan menggunakan teknik pengamatan, wawancara mendalam, dan kajian literatur. Teknik pengamatan yang digunakan adalah pengamatan partisipasi pasif. Literatur yang menjadi bahan pengumpulan data adalah literatur dari jurnal nasional dan internasional. Analisis data dilakukan dengan triangulasi. Hasil penelitian menunjukkan bahwa kondisi budaya etnis yang beragam di Sekolah Dasar Islam Diponegoro memberikan tantangan sekaligus peluang bagi pihak sekolah untuk menanamkan nasionalisme dan watak islamiyah dan keberagaman memberikan bekal nasionalisme yang mendasar karena prinsip-prinsip islamiyah tertanam dalam visi dan misi sekolah.
\end{abstract}

Kata Kunci: multietnis, nasionalisme, pendidikan karakter, pendidikan islamiyah, sekolah dasar.

\title{
A. Pendahuluan
}

Keberagaman di Indonesia meliputi banyak aspek kehidupan. Selain Indonesia memiliki keragaman dalam aspek alam hayati, aspek sosial dan budaya Indonesia juga sangat beragam. Jumlah penduduk Indonesia terbesar dihuni oleh suku Jawa dengan proporsi 40,05 persen dari jumlah penduduk Indonesia, sedangkan suku Sunda kedua dengan besar proporsi 15,50 persen. Suku-suku Indonesia lainnya memiliki proporsi di bawah lima persen dari penduduk Indonesia (Badan Pusat Statistik [BPS], 2018). 
Kondisi keberagaman sosial dari segi etnis menjadi salah satu bonus demografi bagi Indonesia yang memiliki kekayaan suku bangsa. Masyarakat Indonesia terdiri atas masyarakat asli yang telah menduduki beribu-ribu tahun yang lalu sampai datangnya masyarakat imigran yang disebut dengan masyarakat timur asing yaitu Arab dan Cina (Usman, 2009: 1). Sejarah Indonesia menjadikan etnis-etnis awal di negara ini bercampur dengan etnis keturunan dari Imigran di masa lalu, seperti etnis keturunan Arab dan etnis keturunan Cina yang saat ini menjadi kekayaan budaya Indonesia dan disatukan dengan akta Warga Negara Indonesia (WNI). Kondisi perpindahan orang dari negara lain ke negara lainnya terus berkembang. Terlebih lagi negara yang masuk ke dalam kategori negara miskin. Namun, berdasarkan hasil penelitian, pola tersebut sudah berganti menjadi pola migrasi yang multidireksional. Artinya, adanya pergerakan arus migrasi antara negara maju, di antara negara berkembang dengan negara maju. Selain itu, kategori migrasi internal mencapai skala yang besar $(\mathrm{Li}$ \& Heath, 2017: 1).

Keberagaman etnis tersebut di Indonesia secara nyata tidak hanya menghuni di masing-masing pulau, tetapi juga menjadi penduduk di pulau lainnya. Hal tersebut seperti keberagaman etnis di kota Surakarta, Jawa Tengah. Kota Surakarta dikenal sebagai kota budaya Jawa. Banyak warisan kebudayaan Jawa yang ada dan berasal atau bersumber dari kota ini. Sejarah telah membentuk masyarakat kota Surakarta memiliki pemukiman yang secara administratif menunjukkan bahwa pada masa lalu terjadi segregasi etnik (Sutirto, 2000: 87). Kampung etnis keturunan Cina berada di wilayah tertentu dan kampung etnis keturunan Arab juga berada pada wilayah tertentu. Keragaman etnis tersebut berdampingan secara geografis dan sosial. Masyarakat Arab di Kota Surakarta, misalnya, mereka menghuni secara mayoritas, di kecamatan Pasarkliwon. Dengan demikian, kecamatan tersebut sangat mudah ditemui komunitas, penduduk, pedagang yang memang beretnis keturunan Arab. Dengan demikian, masyarakat keturunan Arab yang tinggal di Kota Surakarta di perkampungan mayoritas Arab telah hidup dan tinggal di sana berdampingan dengan etnis Jawa, Madura, dan etnis lainnya. 
Kota Surakarta mewakili salah satu wilayah yang dalam sejarah Indonesia pernah terjadi masalah rasial dan kekerasan terkait dengan etnis dalam kurun waktu tertentu seperti peristiwa pada 20 November 1980. Pada saat itu kerusuhan terjadi di kota Surakarta dan berlanjut ke kota lainnya di Jawa tengah. Kerusuhan tersebut diawali dengan adanya perkelahian pelajar sampai dengan berubah menjadi perusakan dan pembakaran toko-toko milik tionghoa (Usman, 2009: 385). Terjadinya konflik etnis tersebut merupakan salah satu dampak dari kurangnya pemahaman komunitas imajiner kelompok masing-masing etnis terhadap kultur subjektif masyarakat. Hal tersebut menimbulkan konflik yang muncul dikarenakan timbulnya prasangka, dan sikap lainnya (Mahfud, 2014: 131). Oleh karena itu, keberagaman yang ada di suatu wilayah, dapat bermakna ganda, yaitu bonus dan ancaman sosial.

Keberagaman, ideologi dan politik, tata krama, kesenjangan ekonomi, dan kesenjangan sosial perlu dipelajari, sehingga tidak memberi dampak negatif terhadap kehidupan bermasyarakat (Juliardi, 2014: 119). Hal tersebut penting mengingat kasus-kasus negatif saat ini sudah banyak pula menjadikan anak-anak sebagai pelaku tindak kekerasan. Hal tersebut dapat diamati berdasarkan beberapa berita dan hasil penelitian. Salah satunya ditunjukkan melalui hasil penelitian yang menyoroti perilaku anak-anak di sekolah dasar.

Hasil penelitian tersebut menunjukkan bahwa bentuk perilaku sosial negatif yang dilakukan anak dalam hal ini masih belajar di jenjang sekolah dasar adalah membuat keributan, mengganggu teman, berkelahi, mengancam, berbicara tidak sopan, serta menyontek. Berdasarkan penelitian tersebut, perilaku negatif yang ditunjukkan peserta didik disebabkan oleh beberapa faktor. Faktor yang menyebabkan berasal dari internal dan eksternal peserta didik. Penyebab dari faktor internal adalah sikap malas, tidak percaya diri, ingin diperhatikan, serta ingin menutupi kekurangannya. Penyebab yang berasal dari faktor eksternal yaitu kurangnya dukungan positif baik dari lingkungan keluarga, lingkungan sekolah, maupun lingkungan masyarakat terhadap upaya meminimalisasi berkembangnya perilaku negatif 
pada anak. Dengan demikian, perilaku negatif yang dilakukan anak akan menyebabkan prestasi belajar kurang tercapai secara optimal dan juga berdampak kepada tidak diterima oleh kelompok sebaya. Selain itu, dampak sosial lainnya yang akan diterima anak dengan perilaku negatif adalah dipandang negatif oleh guru (Riyani, 2011:v).

Dekadensi moral dan perilaku tidak terpuji, seperti kekerasan, tawuran, eksklusivisme dan lemahnya toleransi serta penghargaan terhadap orang lain yang semakin meningkat menjadi indikator bahwa fungsi pendidikan islam yang dijalankan selama ini belum efektif (Zain, 2013: 1). Keterlibatan anak-anak dalam kerusuhan terkait rasial ini menjadi masalah yang yang berbahaya dan sangat penting untuk segera dicari solusi sebagai upaya pencegahan.

Banyaknya peristiwa kerusuhan yang melibatkan kalangan pelajar perlu dikembangkan suatu model pendidikan islam yang multikultural. Selain itu, fokus pendidikan multikultural tadi adalah pada menginternalisasikan kesadaran pentingnya menghormati keragaman dan memberikan pengakuan kesederajatan paedagogis kepada semua yang berhak tanpa adanya diskriminasi. Dengan demikian, lembaga pendidikan akan menumbuhkan suasana lingkungan yang toleran, demokratis, humanis, inklusif, dan sinergis bagi semua peserta didik tanpa terkecuali perbedaan latar belakang (Zain, 2013: 1).

Upaya tersebut melibatkan semua pihak, salah satunya pihak di dunia pendidikan formal. Oleh karena itu, karakter budaya Indonesia yang sangat multikarakteristik ini mempengaruhi pembentukan kebijakan pemerintah dalam berbagai bidang seperti halnya pendidikan. Hal tersebut dikarenakan suatu kebijakan pendidikan dipengaruhi karakteristik penduduknya. Dengan demikian, kondisi tersebut juga terjadi di Kota Surakarta.

Pendampingan peserta didik agar berlangsung secara wajar, ideal, dan normal adalah peran dan fungsi lembaga pendidikan, seperti halnya di sekolah dasar (Irham \& Wiyani, 2014: 32). Lembaga pendidikan juga disebut sebagai sistem sosial dikarenakan di dalam pendidikan akan terjadi proses sosialisasi (Zafi, 2017: 1). Berkaitan dengan perkembangan manusia, 
lembaga sosialisasi terkuat adalah sekolah dasar (Gibson \& Mitchell, 2011: 81).

Selain itu, saat anak mengikuti pendidikan di jenjang sekolah dasar, pada saat itu merupakan saat-saat yang sangat penting untuk perkembangan psikososial peserta didik (Lin \& Chen, 2016: 1). Dengan demikian, melalui pendidikan di sekolah dasar diharapkan peserta didik dapat memiliki kemampuan dasar untuk melanjutkan ke jenjang selanjutnya dan mendukung tercapainya tugas-tugas perkembangan yang dialami secara baik. Hal tersebut dikarenakan usia SD adalah usia yang sangat penting dalam mengembangkan psikososial anak. Urgensi pendidikan karakter nasionalisme dalam aspek keberagaman sangat penting ditumbuhkan pada diri anak sejak dini.

Karakter adalah nilai umum perilaku manusia yang berhubungan dengan Tuhan, diri sendiri, sesama manusia, dan dengan lingkungan. Lingkungan yang dimaksudkan terwujud dalam bentuk pikiran, sikap, perasaan, perkataan, dan perbuatan. Hal tersebut berdasarkan norma-norma agama, hukum, tata krama, budaya dan adat istiadat (Suyadi, 2013: 5-6). Pendidikan karakter dalam islam adalah pendidikan yang mencakup pengetahuan moral, perasaan tentang moral, dan perbuatan moral. Moral-moral tersebut dikembangkan berdasarkan nilai-nilai Islam (Muhsinin, 2013: 1).

Berdasarkan latar belakang di atas, tujuan penelitian ini untuk menggali karakter nasionalis dalam perwujudan islami antara peserta didik yang memiliki etnis berbeda-beda di sekolah dasar berbasis agama Islam. Penelitian ini menggunakan penelitian kualitatif. Penelitian kualitatif adalah penelitian yang dimulai dengan asumsi dan kerangka kajian teoritis. Dengan demikian, keduanya menjadi landasan dalam penelitian yang berkaitan dengan masalah yang akan dijadikan penelitian (Creswell, 2015: 59). Selain itu, dinyatakan pula bahwa metode kualitatif sebagai suatu proses evolusi yang mengkaji suatu fenomena yang yang diteliti dan harus menunjukkan hubungan dengan pertanyaan yang sedang dieksplorasi (Ward, Comer, \& Stone, 2018: 1).

Penelitian kualitatif memiliki peran utama dalam hal permasalahan dan kontekstual (Russell, Berney, Stansfeld, Lanz, 
Kerry, Chandola, \& Bhui, 2016: 1). Oleh karena itu, dalam penelitian ini mengkaji mengenai masalah pendidikan di sekolah islam yang memiliki keragaman etnis dalam menginternalisasikan karakter nasionalisme antarpeserta didik. Dengan demikian, objek penelitian ini yaitu internalisasi pendidikan karakter nasionalisme di tengah keberagaman etnis peserta didik. Instrumen utama dalam penelitian ini adalah peneliti. Data yang digunakan dalam penelitian ini adalah data dari informasi lisan yang berkaitan dengan hasil wawancara dan data aktivitas subjek yang berkaitan dengan hasil observasi.

Sekolah yang digunakan sebagai tempat penelitian adalah Sekolah Dasar Islam Diponegoro, Kota Surakarta. Kondisi peserta didik di sekolah tersebut mayoritas merupakan beretnis Arab, sedangkan minoritasnya adalah peserta didik beretnis Jawa dan Madura. Sekolah tersebut dipilih menjadi latar penelitian karena alasan-alasan berikut: (1) Letak sekolah berada di wilayah yang menjadi pemukiman etnis keturunan Arab di Kota Solo. (2) Selain letaknya di pusat keturunan Arab, sekolah tersebut juga berdampingan dengan wilayah kebudayaan Jawa. Hal tersebut dikarenakan letak kota Surakarta menjadi pusat kebudayaan Jawa yang ditunjukkan dengan keberadaan Keraton Pura Mangkunegaran dan Keraton Kasunanan Surakarta di kota tersebut (Saddhono \& Rohmadi, 2014: 25). Oleh karena itu, ada dua budaya yang berkembang yang pada suatu sudut pandang tertentu keduanya dapat bermakna mayoritas. Artinya, dominasi peserta didik multietnis dari keturunan Arab, tetapi ada pada sentra kultur Jawa yang kental. (3) Peserta didik di sekolah tersebut dapat dinyatakan sebagai multietnis karena terdiri dari lebih dari dua etnis, yaitu etnis Arab sebagai mayoritas, etnis Jawa, dan etnis Madura.

Peneliti sebagai instrumen utama juga membutuhkan instrumen tambahan agar dapat mengumpulkan data sebaikbaiknya. Teknik pengumpulan data lainnya yang digunakan, yaitu wawancara dan observasi. Teknik wawancara yang dipilih, yaitu wawancara mendalam. Wawancara mendalam adalah mengajukan pertanyaan-pertanyaan yang bersifat terbuka, sehingga narasumber dapat memberikan jawaban yang lebih luas. Selain itu, 
pengajuan pertanyaan terbuka akan menyebabkan narasumber menjawab pengalamannya tanpa dibatasi oleh perspektif peneliti dan temuan penelitian sebelumnya (Sukmadinata, 2011: 112). Kemudian, jawaban terbuka dari narasumber terkait terhadap pertanyaan akan menyebabkan narasumber menciptakan opsiopsi untuk merespon (Cresswell, 2015: 430).

Informan dalam kegiatan wawancara ini, yaitu kepala sekolah, guru kelas, dan beberapa peserta didik. Data wawancara yang diambil yaitu mengenai internalisasi pendidikan karakter dan mengenai keragaman etnis. Proses wawancara dilakukan baik secara formal maupun informal. Selain itu, observasi yang digunakan, yaitu jenis observasi partisipasi berperan pasif. Jenis observasi berperan pasif digunakan karena peneliti hanya berperan sebagai pengamat. Subjek penelitian dalam kegiatan observasi ini adalah aktivitas peserta didik baik di dalam maupun di luar kelas dan beberapa pembelajaran yang dilakukan guru. Data yang diambil dalam kegiatan observasi adalah keinklusifan pembelajaran dan interaksi peserta didik.

Penyusunan laporan penelitian kualitatif seperti halnya sifat iteratif dari proses penelitian kualitatif, yaitu suatu analisis data dilakukan seiring dengan proses penulisan (Korstjens \& Moser, 2018: 1). Dinyatakan pula analisis data dilakukan secara terus-menerus sepanjang penelitian dari awal sampai akhir penelitian. Hal tersebut dilakukan karena pengamatan yang dilakukan dalam penelitian tidak dapat dilakukan tanpa analisis dan penafsiran untuk mengkaji makna yang didapat. Selain itu, analisis data dilakukan untuk pengembangan teori berdasarkan data (Nasution, 1996: 35).

Berdasarkan hal di atas, penelitian ini melakukan proses analisis data melalui komponen analisis data interaktif. Keabsahan data (validitas) dilakukan dengan cara triangulasi metode. Triangulasi merupakan teknik peningkatan keabsahan data yang menggunakan lebih dari satu cara pandang untuk menarik suatu simpulan. Dengan demikian, hasil dari beberapa cara pandang tersebut akan dapat dipertimbangkan secara beragam dari segi fenomena, perbedaan dan persamaan, dan lainnya. Dengan demikian, nantinya didapat simpulan yang lengkap (Sutopo, 
2006: 92-93). Keabsahan data akan mengarah kepada kebenaran dan representasi akurat dari informasi yang disajikan (Cozby, 2009: 138).

\section{B. Pembahasan}

Kondisi budaya etnis yang beragam di Sekolah Dasar Islam Diponegoro memberikan tantangan dan peluang bagi pihak sekolah untuk menanamkan nasionalisme dan watak islamiyah.

Tabel 1. Aspek dalam Penanaman Karakter

\begin{tabular}{|c|c|c|}
\hline No & Aspek & Deskripsi \\
\hline 1. & $\begin{array}{l}\text { Budaya } \\
\text { kelas }\end{array}$ & $\begin{array}{l}\text { Peraturan yang digunakan di dalam kelas menggunakan } \\
\text { pedoman "adab rasul” yang terdiri dari beberapa butir. } \\
\text { Setiap butir adab yang tertera membantu peserta didik } \\
\text { mengembangkan karakter berbudi pekerti yang islamiyah } \\
\text { dalam keberagaman setiap peserta didiknya. }\end{array}$ \\
\hline & $\begin{array}{l}\text { Budaya } \\
\text { sosialisasi }\end{array}$ & $\begin{array}{l}\text { Pertemanan saling membaur, sehingga tidak tampak setiap } \\
\text { peserta didiknya menjadikan salah satunya terasing di dalam } \\
\text { pergaulan mereka di dalam kelas. } \\
\text { Sosialisasi antar teman juga diajarkan mengenai adab } \\
\text { kesantunan antar teman yang berbeda lawan jenis. Hal ini, } \\
\text { secara tidak langsung juga mengajarkan mengenai saling } \\
\text { menghormati dan pengenalan pendidikan seks sejak dini. }\end{array}$ \\
\hline & $\begin{array}{l}\text { Budaya } \\
\text { belajar }\end{array}$ & $\begin{array}{l}\text { Kegiatan belajar dilakukan berpola oleh sistem kelas. Pola yang } \\
\text { digunakan adalah perubahan tata letak tempat duduk yang } \\
\text { dilakukan secara periodik. Dengan demikian, setiap peserta } \\
\text { didik memiliki peluang untuk berada di dekat peserta didik } \\
\text { lainnya yang berbeda-beda setiap harinya. }\end{array}$ \\
\hline
\end{tabular}

\section{Budaya Kelas dalam Integrasi Penanaman Karakter Nasionalis Antaretnis}

Pendidikan spiritual penting untuk dikaji ulang mengenai pentingnya dalam bidang pendidikan. Hal tersebut dikarenakan aspek ini menjadi bagian integral dari ajaran Islam (Mufid, 2016: 1). Keberagaman peserta didik yang ada di sekolah menjadi tantangan tersendiri untuk menerapkan sistem pendidikan.

Sistem pendidikan harus memenuhi kebutuhan peserta didik minoritas untuk memberi kesempatan yang sama (Açikalin, 2010: 1). Selain itu, budaya di suatu lembaga dipengaruhi oleh semua warga yang ada di dalamnya. Pernyataan tersebut relevan 
dengan hasil penelitian yang menyatakan pembelajaran perlu memberdayakan lingkungan sebagai sumber belajar. Selain itu, pembelajaran juga memberi kesempatan kepada peserta didik untuk mengekspresikan kemampuan interpersonalnya. Dengan demikian, peserta didik merasa senang meskipun memiliki teman-teman yang beragam dalam latar belakang budayanya. Oleh karena itu, pendidikan harus peka terhadap karakteristik budaya yang dimiliki peserta didiknya (Maknun, 2013: 1). Hal tersebut dikarenakan visi dan misi mempunyai pengaruh yang penting dalam membentuk budaya di sebuah lembaga pendidikan (Setyaningsih \& Subiyantoro, 2017: 1). Dengan demikian diperlukan kebijakan untuk mencapai tujuan yang diinginkan. Kebijakan tersebut harus mengarah kepada visi dan misi.

Pelaksanaan kebijakan tersebut salah satunya perlu diterapkan dalam proses belajar-mengajar di kelas. Kondisi kelas menjadi penting karena kelas menjadi tempat berbagi latar belakang, karakter, kepribadian, tingkah laku, dan emosi yang berbeda-beda (Zahroh, 2015: 1). Pembelajaran berlangsung dalam suatu adegan kelas. Adegan kelas perlu dikembangkan menjadi sarana berlangsungnya pembelajaran yang efektif (Sunhaji, 2014: 1). Oleh karena itu, untuk mewujudkan internalisasi berbagai karakter sesuatu tujuan, perlu ada pengelolaan kelas yang baik.

Pengelolaan kelas adalah pemberdayaan potensi kelas untuk menumbuhkan iklim pembelajaran yang kondusif, positif, produktif, dan efektif. Selain itu, pengelolaan kelas juga berfungsi untuk mengendalikan kondisi kelas jika terjadi masalah dalam pembelajaran (Istihana, 2015: 267). Dengan demikian, pendekatan dalam pengelolaan kelas agar pembelajaran menjadi efektif dapat dilakukan melalui pendekatan kekuasaan, pendekatan ancaman, pendekatan kebebasan, pendekatan resep, pendekatan pembelajaran, pendekatan perubahan tingkah laku, pendekatan suasana emosi dan hubungan sosial, pendekatan proses kelompok, dan pendekatan elektis atau pluralistic (Zahroh, 2015: 1). Hal tersebut seperti halnya yang muncul dalam pengamatan di lapangan. Peraturan yang digunakan di dalam kelas menggunakan pedoman "Gerakan Adab Rasul (I)" yang terdiri dari butir-butir berikut: 
Tabel 2. Butir-butir Gerakan Adab Rasul (I)

\begin{tabular}{ll}
\hline Adab Beribadah & 1. Sholat fardhu di rumah. \\
2. Tadarus Alquran di rumah
\end{tabular}

Pengaturan tersebut tidak menyebabkan adanya eksklusivitas terhadap murid tertentu saja. Selain itu, peraturan di atas juga secara implisit mengembangkan berbagai pendekatan sekaligus, yaitu pendekatan kekuasaan (pendidik kepada terdidik), pendekatan ancaman (hukum peraturan), pendekatan pembelajaran (tujuan peraturan), pendekatan perubahan tingkah laku (desain peraturan), pendekatan suasana emosi dan hubungan sosial (proses pelaksanaan peraturan), pendekatan proses kelompok (proses pelaksanaan peraturan), dan pendekatan 
elektis atau pluralistic (proses pelaksanaan peraturan) (Zahroh, 2015: 1).

Hal ini sama seperti temuan penelitian pada subjek kelompok remaja bahwa perilaku orang dewasa yang memberikan fasilitas sama kepada setiap peserta didik maka akan memunculkan sosialisasi yang positif. Hal di atas juga seiring dengan pernyataan bahwa pola pendidikan nilai budaya dilaksanakan secara efektif melalui membiasakan bertingkah laku, pemberian contoh dan penciptaan suasana harmonis (Wardani, 2015: 1). Kondisi di atas, dapat dimaknai sebagai pengaturan yang akan membiasakan peserta didik dalam bergaul di sekolah. Hal tersebut relevan dengan peran lembaga pendidikan dapat melakukan pembiasaan melalui program-program yang disusun. Pembiasaan yang telah terjadi akan menjadi pembudayaan. Oleh karena itu, pengaturan Adab Rasul dan pembiasaan lainnya harus dijaga dengan kontrol yang baik oleh sekolah.

Melalui pengaturan di atas, secara tidak langsung sekolah telah berupaya untuk memberlakukan sama kepada semua peserta didik dalam proses belajar di lingkungan sekolah yang sejalan dengan visi-misi sekolah. Dengan demikian, akan terhindar adanya peserta didik yang merasa terdiskriminasi secara tidak langsung, baik melalui psikologis maupun secara perlakuan fisik dalam pembelajaran. Etnis minoritas yang cenderung sering kali mendapatkan tindakan diskriminasi dari guru, kelompok tersebut akan menjadi kelompok yang berisiko. Hal tersebut menjadi fakta bahwa sosialisasi terkait budaya dapat meningkatkan citra positif latar belakang remaja (D'hondt, Eccles, Houtte, \& Stevens, 2016: 1).

Setiap peserta didik secara tidak langsung saling memahami bahwa antarteman memiliki hak dan kewajiban yang sama di dalam kelas, meskipun memiliki latar belakang etnis yang berbeda. Anak-anak sebagai peserta didik merupakan individu yang dapat dididik, dapat dilatih, dan dapat belajar (Chasiyah, Chadidjah, \& Legowo, 2009: 15-16). Dengan demikian, anggapan belum efektifnya pendidikan karakter yang terjadi dapat disebabkan karena kurangnya pengajaran nilai keimanan dan konsep adab (Zamhari \& Masamah, 2016: 1). 


\section{Budaya Sosialisasi dalam Integrasi Penanaman Karakter Nasionalis Antaretnis}

Ahli psikologi menyebut usia anak sekolah dasar sebagai usia berkelompok. Disebut sebagai usia berkelompok karena pada masa tersebut anak-anak akan mengalami anak tertuju pada keinginan untuk dapat diterima oleh teman sebaya sebagai anggota kelompok, terutama kelompok yang dianggap hebat dalam pandangan teman-temannya. Hal tersebut juga akan menyebabkan anak akan menyesuaikan diri dengan standar yang disetujui kelompok tersebut, yaitu dalam hal penampilan, berbicara, dan perilaku. Berdasarkan kondisi tersebut, selain disebut sebagai usia berkelompok, anak usia sekolah dasar juga disebut sebagai periode usia penyesuaian diri (Hurlock, 1980: 146).

Sosialisasi antar teman diajarkan mengenai adab kesantunan antar teman baik sesama perempuan maupun antarteman yang berbeda lawan jenis. Kelas yang terpisah berdasarkan gender akan menunjukkan suatu perbedaan terhadap pola interaksi kelas yang ditimbulkan. Interaksi di kelas dapat mengembangkan kemampuan mengekspresikan diri dalam interaksi (Cihan \& Yildirim, 2014: 1039). Selain itu, pemisahan antara laki-laki dan perempuan dapat disebut sebagai sarana untuk menjaga kerendahan hati dan sebagai kebutuhan untuk mendidik dan melatih laki-laki dan perempuan terhadap peran sosial masing-masing. Pandangan tersebut termasuk ke dalam budaya konservatif (Brandes, 2012: 1). Perhatikan pola Diagram 1 berikut ini.

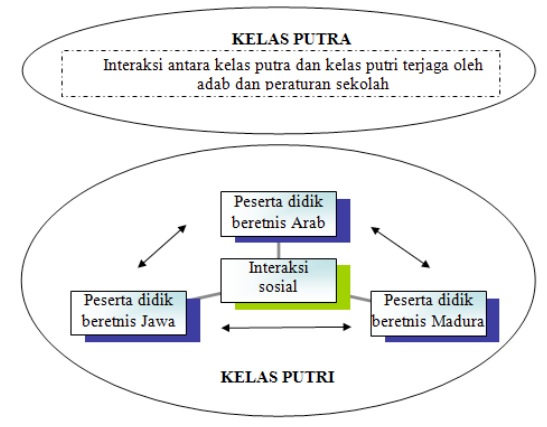

Diagram 1. Pola Interaksi antarpeserta Didik di Kelas Putri dan interaksi kelas Putri dengan Kelas Putra 
Berdasarkan diagram 1, pertemanan yang terjadi di kelas tampak tidak menunjukkan pola khusus setiap etnisnya, tetapi setiap peserta didik dari etnis Arab, Jawa, dan Madura saling membaur. Namun, pengecualian terjadi dengan pola sosialisasi antarteman yang berbeda jenis kelamin. Dalam hal tersebut, ada perpaduan antarkarakter, seperti saling menghormati dan menyayangi antarteman dan saling menjaga pula antarmereka. Hal ini, secara tidak langsung juga mengajarkan mengenai saling menghormati dan pengenalan pendidikan seks sejak dini. Oleh karena itu, aspek religiusitas, hierarki gender, dan kehormatan merupakan termasuk ke dalam beberapa dasar dari budaya Islam yang dapat dikenali (Vandello, 2016: 1).

Pertemanan yang membaur menjadikan setiap peserta didiknya tidak tampak menjadikan salah satunya terasing di dalam pergaulan mereka di dalam kelas. Pembauran terjadi antarteman baik peserta didik beretnis Arab, Jawa, maupun Madura salah satunya didukung oleh sistem kelas.

Tabel 3. Integrasi Antarpeserta Didik dalam Sistem Kelas IV Putri

\begin{tabular}{|c|c|c|c|c|c|c|}
\hline \multirow{2}{*}{$\begin{array}{c}\text { Jenis } \\
\text { Kelompok }\end{array}$} & \multicolumn{6}{|c|}{ Sebaran Peserta didik pada Kelompok } \\
\hline & I & II & III & IV & $\mathbf{V}$ & VI \\
\hline \multirow[t]{5}{*}{ Regu Piket } & $\mathrm{P} 1^{*}$ & P18*, & P14*, & P10*, & $\mathrm{P}^{*}$ & P2*, \\
\hline & P23, & P19*, & P15**, & P11**, & $\mathrm{P}^{*}$ & P3*, \\
\hline & P24, & P20*, & $\mathrm{P} 16^{* *}$ & P12**, & P8*, & $\mathrm{P}^{*}, \mathrm{P}^{* *}$ \\
\hline & $\mathrm{P} 25$, & $\mathrm{P} 21^{*}$, & $\mathrm{P} 17^{*}$ & $\mathrm{P} 13^{* *}$ & $\mathrm{P} 9^{* * *}$ & \\
\hline & $\mathrm{P} 2^{*}$ & $\mathrm{P} 22^{*}$ & & & & \\
\hline
\end{tabular}

\begin{tabular}{|c|c|c|c|c|c|c|}
\hline Regu Belajar & $\begin{array}{l}\text { P2*, } \\
\text { P3*, } \\
\text { P15, } \\
\text { P24, } \\
\text { P4* } \\
\text { P2* }\end{array}$ & $\begin{array}{l}\mathrm{P} 7^{*} \\
\mathrm{P} 14^{*} \\
\mathrm{P} 6^{*} \\
\mathrm{P} 13^{* *} \\
\mathrm{P} 21^{*}\end{array}$ & $\begin{array}{l}\mathrm{P} 25^{*}, \\
\mathrm{P} 8^{*} \\
\mathrm{P} 11^{* *} \\
\mathrm{P} 2^{*} \\
\mathrm{P} 26^{*}\end{array}$ & $\begin{array}{l}\text { P23*, } \\
\text { P22*, } \\
\text { P10*, } \\
\text { P5**, } \\
\text { P9*** }\end{array}$ & $\begin{array}{l}\mathrm{P} 12^{* *}, \\
\mathrm{P} 17^{*}, \\
\mathrm{P} 18^{*}, \\
\mathrm{P} 16^{* *} \\
\mathrm{P} 1{ }^{*} \\
\mathrm{P} 19^{*}\end{array}$ & - \\
\hline
\end{tabular}

\section{Keterangan:}

* peserta didik beretnis Arab

** peserta didik beretnis Jawa

*** peserta didik beretnis Madura 
Berdasarkan Tabel 3, sistem kelas yang telah dibentuk baik dalam kelompok piket maupun kelompok belajar menunjukkan adanya upaya sosialisasi yang inklusi dan menginternalisasikan kebersamaan sebagai persatuan antarteman dalam keberagaman latar belakang etnis.

Apabila peserta didik yang berbeda etnis merasa tidak nyaman dengan teman lainnya yang berbeda etnis, hal tersebut akan berdampak kepada meningkatnya perilaku bermasalah di sekolah. Apabila ada peserta didik yang berperilaku bermasalah, berdasarkan penelitian, pada diri seorang remaja akan mendorong remaja untuk juga terlibat dalam perilaku bermasalah (Geven, Kalmijn, \& Van Tubergen, 2016: 1). Berdasarkan penelitian di Taiwan, peserta didik Aborigin sering memiliki perasaan bahwa harga diri mereka rendah dan cenderung memiliki pandangan negatif mengenai kehidupan mereka karena latar belakang yang dimiliki berbeda dengan komunitas mayoritas di sekolahnya (Chen \& Lee, 2015: 1).

Perbedaan setiap peserta didik dari latar belakang etnis tidak ada yang begitu signifikan. Interaksi peserta didik tidak ada perbedaan perilaku secara khusus. Perbedaan hanya muncul dalam bidang akademik, yaitu mata pelajaran agama. Oleh karena itu, peserta didik yang beretnis Arab tentu di keluarganya memiliki pembiasaan kegiatan agama yang lebih terpola dengan baik. Perbedaan segi perilaku di kelas putri ini tidak ada perbedaan. Namun, dalam pelajaran agama serta tingkat kereligiusan anak dapat dirasakan.

Peserta didik beretnis Arab tentu di keluarganya memiliki pembiasaan kegiatan agama yang lebih terpola dengan baik. Berdasarkan observasi, pertemanan yang terjadi di kelas tampak tidak menunjukkan pola khusus setiap etnisnya, tetapi setiap peserta didik dari etnis Arab, Jawa, dan Madura saling membaur. Namun, pengecualian terjadi dengan pola sosialisasi antarteman yang berbeda jenis kelamin. Dalam hal tersebut, ada perpaduan antarkarakter, seperti saling menghormati dan menyayangi antarteman dan saling menjaga pula antarmereka. Kelebihan kelas yang fokus pada jenis kelamin yang sama adalah bisa membatasi pergaulan. Hal tersebut dikarenakan SD Islam Diponegoro 
memiliki visi dan misi yang berbeda dengan sekolah negeri yang kelasnya campur antara putra dan putri.

Berdasarkan hal di atas, dari segi interaksi peserta didik tidak ada perbedaan perilaku secara khusus. Perbedaan hanya muncul dalam bidang akademik, yaitu mata pelajaran agama. Anak-anak membawa persepsi tertentu mengenai identitas mereka dari latar belakang mereka masing-masing (Baig, 2015: 1). Oleh karena itu, peserta didik yang beretnis Arab tentu di keluarganya memiliki pembiasaan kegiatan agama yang lebih terpola dengan baik. Pernyataan tersebut didukung oleh hasil penelitian Sadik, Çakan, \& Artut (2011: 1) bahwa perbedaan kondisi sosial peserta didik dapat menunjukkan perbedaan yang signifikan meskipun masing-masing memiliki usia dan karakteristik perkembangan kognitif yang sama. Hal tersebut didukung sebuah riset bahwa peserta didik sebagai anak telah memiliki fitrah yang baik.

Kebudayaan dan pendidikan saling berkaitan untuk mengembangkan karakter yang positif. Oleh karena itu, keanekaragaman antarbudaya dalam bidang pendidikan merupakan inti untuk memastikan bahwa etnisitas positif (Kibui, 2015: 1). Berbagai kasus mengenai kondisi negatif hubungan keberagaman sangat berbahaya saat melibatkan individu-individu yang masih usia sekolah. Menurut sebuah riset, saat suatu bangsa terus fokus kepada isu kekerasan yang terjadi di sekolah, peserta didik sebanyak lebih dari 160.000 telah kehilangan kesempatan untuk dapat bersekolah setiap harinya. Penyebab yang menimbulkan kasus tersebut adalah peserta didik mendapatkan gangguan atau tindakan yang kurang baik dari teman lainnya (Koonce \& Mayo, 2013: 1).

Hal tersebut diperkuat juga dengan hubungan pertemanan berpengaruh terhadap cara peserta didik dalam memikirkan masalah sosial dan moral (Mc Donald, Malti, Killen, \& Rubin, 2014: 1). Akhir masa kanak-kanak dikenal sebagai usia berkelompok. Pada masa ini akan ditandai adanya minat terhadap aktivitas bersama teman-teman dan meningkatnya keinginan yang kuat untuk diterima sebagai anggota suatu kelompok, dan merasa tidak puas bila tidak bersama mereka. Oleh karena itu, pada masa ini anak akan merasa tidak puas apabila bermain seorang diri 
bahkan hanya dengan saudara kandung/anggota keluarganya sendiri (Hurlock, 1980: 155-156).

Teman-teman yang memberikan penolakan kepada peserta didik lainnya menjadi kajian yang menarik beberapa tahun terakhir. Hal ini dikarenakan pengalaman teman bermain pada masa anakanak diprediksi akan memberikan dampak kurang baik kepada perkembangan anak pada masa selanjutnya (Mikami, Lerner, \& Lun, 2010: 1). Hal tersebut juga didukung dengan penelitian yang menyatakan bahwa peserta didik yang mengalami latar belakang keluarga kurang baik dan mempunyai masalah psikososial akan menjadikan mereka cenderung tidak memiliki hubungan yang baik dengan teman sebayanya. Hal tersebut menjadikan anak-anak dan remaja tidak dapat memiliki hubungan baik dengan teman sebayanya (Demir \& Kaya, 2008: 1).

Dengan demikian, kebutuhan anak-anak pada periode ini tentunya sangat perlu difasilitasi dengan pemenuhan sekolah dalam kebutuhan peserta didik. Anak ingin bersama dengan kelompoknya dikarenakan anak akan mendapatkan kesempatan untuk bermain, berolahraga, dan memberikan kegembiraan. Oleh karena itu, sejak anak masuk sekolah sampai dengan masa pubertas anak-anak memiliki keinginan untuk bersama dan dapat diterima oleh kelompok akan semakin kuat. Hal ini berlaku baik untuk anak laki-laki maupun anak perempuan (Hurlock, 1980: 156).

\section{Budaya Belajar dalam Integrasi Penanaman Karakter Nasionalis Antaretnis}

Selain berdasarkan sistem kelas dalam suatu struktur, hal ini juga tampak pada kebijakan kelas yang telah disetujui bersama, seperti penataan dan pembagian kelas. Perubahan tata letak tempat duduk yang dilakukan secara periodik. Tempat duduk yang terpola dan berubah secara periodik akan mendukung interaksi peserta didik antaretnis yang efektif. Seperti penelitian yang dilakukan Cihan dan Yildirim (2014: 1041) menyimpulkan bahwa pola tempat duduk yang berubah dan nyaman baik bagi guru dan peserta didik akan mendukung berkembangnya interaksi yang efektif. 
Aturan kelas dalam kegiatan belajar sangat memberikan pengaruh terhadap perkembangan peserta didik. Setiap peserta didik memiliki peluang untuk berada di dekat peserta didik lainnya yang berbeda-beda setiap harinya. Dengan demikian, guru harus memiliki kompetensi yang dapat mendukung terjadinya interaksi sosial yang baik di antara peserta didik. Melalui model tersebut diharapkan dapat semakin mendukung berkembangnya kemampuan sosial peserta didik kemampuan sosial (Cihan \& Yildirim, 2014: 1039).

Berdasarkan riset lainnya, kondisi anak-anak Wabankaki di Maine dan Kanada timur juga telah berasimilasi ke sekolahsekolah yang didirikan imigran Eropa lebih dari 400 tahun. Namun, kondisi kualitas yang buruk menjadi tantangan dalam kelangsungan hidup budaya dan masyarakat adat. Selain itu, penduduk asli Amerika Utara yang merupakan populasi minoritas memiliki tantangan yang unik. Minoritas imigran harus dapat berasimilasi ke dalam masyarakat mayoritas, memperkaya unsurunsur latar belakang budaya. Dengan demikian, masyarakat adat diharuskan untuk berasimilasi dengan budaya imigran (Putnam, Putnam, Jerome, \& Jerome, 2011: 1).

Kondisi tersebut menjadi pembeda dalam penelitian ini. Kondisi belajar kelas tidak menjadikan setiap peserta didik untuk demikian. Namun, kondisi yang ada lebih kepada pembauran dalam hal interaksi antarteman yang berbeda dan didukung dengan konsep belajar oleh guru. Konsep belajar tersebut, yaitu dari pola tempat duduk, kerja kelompok, dan perilaku inklusif guru dalam pembelajaran.

Pendidikan karakter penting dalam membentuk kepribadian peserta didik. Namun, saat ini guru hanya mengimplementasikan konsep pendidikan karakter tanpa memahami teori dasar yang mendasari (Nida, 2013: 1). Dengan demikian, membentuk peserta didik yang berkarakter unggul membutuhkan tindakan yang tidak mudah. Oleh karena itu, hal tersebut memerlukan upaya berkelanjutan dan refleksi mendalam.

Karakter positif perlu dikembangkan dengan berbagai metode seperti halnya pengembangan pendidikan islami (Sulthon, 2016: 399). Selain itu, khusus pada anak perempuan, mereka 
lebih memiliki banyak keterlibatan dalam penalaran konvensional moral dan sosial daripada anak laki-laki (McDonald, Malti, Killen, \& Rubin, 2014: 5). Hal tersebut dikarenakan anak saat berusia sekolah dasar, mereka akan cenderung memunculkan suatu sikap atau kondisi yang sangat berpengaruh terhadap cara mereka menyesuaikan citra pribadi dan kondisi sosial anak (Hurlock, 1980: 146).

Dengan demikian, perpaduan keputusan atau kebijakan sekolah dalam pengembangan aturan dan budaya sangat berkaitan dengan kondisi keberagaman di sekolah tersebut. Berkaitan dengan pendidikan dalam ranah sekolah islam, tentunya mengarah kepada pengembangan pendidikan yang berupaya menginternalisasikan karakter-karakter pancasilais dan berwatak islami. Peran sekolah sangat penting dan dapat didukung melalui berbagai program yang mendukung internalisasi karakter nasionalisme. Hal tersebut dikarenakan faktor yang mempengaruhi konsep diri pada akhir masa kanak-kanak adalah lingkungan sekolah yang mana di sanalah anak-anak juga banyak berinteraksi dengan teman sebayanya.

Selain itu, pihak yang sangat dekat dengan peserta didik di sekolah sekaligus sebagai orang tua, yaitu guru, juga harus terus mengembangkan kompetensinya agar semakin dapat memenuhi kebutuhan peserta didik yang memang sangat multikultural. Oleh karena itu, guru memiliki banyak peran di sekolah tidak terkecuali dalam hal memahami dinamika pertemanan antarpeserta didiknya, menciptakan lingkungan kelas yang mengembangkan keterampilan interpersonal yang positif. Selain itu, guru juga harus terlibat dalam pencegahan tindakan negatif antarpeserta didik dan mencegah adanya risiko dalam penyesuaian emosi pada peserta didik mereka (Troop-Gordon, 2015: 1). Dengan demikian, pendidikan karakter harus dilaksanakan dengan melibatkan berbagai pihak, di keluarga dan rumah tangga, lingkungan sekolah, dan masyarakat (Subianto, 2013: 1). Dengan demikian, diharapkan adanya sinergitas antarpihak pendidikan karakter dapat memunculkan karakter bangsa yang saling mencintai keberagaman.

Kondisi pluralnya masyarakat akan mendukung terjadinya dinamika masyarakat yang unik. Selain itu, apabila individu 
terikat pada identitas kelompoknya, maka akan menumbuhkan sikap etnosentrisme, prasangka ingroup-outgroup, dan berkembangnya stereotip yang akan mempengaruhi kualitas hubungan antar kelompok. Upaya yang dilakukan untuk mengembangkan pluralisme di masyarakat agar konstruktif dan beradab dapat dilakukan melalui asimilasi, integrasi, melting pot, multikulturalisme, dan sebagainya (Susetyo, 2010: 12).

Proses menyesuaikan diri akan berjalan efektif apabila didukung oleh guru yang kompeten dan yang penuh pengertian. Hal tersebut dikarenakan apabila guru menerapkan disiplin yang dianggap tidak adil oleh anak atau yang menentang anak akan memberi pengaruh yang berbeda. Selanjutnya adalah faktor dukungan sosial secara langsung dari pihak lain. Dukungan atau kurangnya dukungan dari teman-teman akan mempengaruhi kepribadian anak melalui konsep diri yang terbentuk. Hal ini akan menjadi masalah yang rentan karena yang paling terpengaruh adalah anak yang sangat populer dan anak yang terisolasi dari sosialisasi pertemanan mereka (Hurlock, 1980: 173).

\section{Simpulan}

Dari uraian diatas, penulis menyimpulkan bahwa keberagaman memberikan bekal nasionalisme yang mendasar karena prinsip-prinsip islamiyah tertanam dalam visi dan misi sekolah. Misi yang dijalankan terintegrasi dalam berbagai kebijakan, seperti terkait dengan budaya di dalam kelas, budaya bersosialisasi antarteman yang berbeda etnis, dan budaya belajar. Budaya kelas mengembangkan peraturan yang digunakan di dalam kelas menggunakan pedoman "Gerakan Adab Rasul (I)". Melalui pengaturan tersebut secara tidak langsung sekolah telah berupaya untuk memberlakukan sama kepada semua peserta didik dalam proses belajar di lingkungan sekolah yang sejalan dengan visi-misi sekolah. Dengan demikian, akan terhindar adanya peserta didik yang merasa terdiskriminasi secara tidak langsung, baik melalui psikologis maupun secara perlakuan fisik dalam pembelajaran. Pertemanan yang terjadi di kelas tampak tidak menunjukkan pola khusus setiap etnisnya, tetapi setiap peserta didik dari etnis Arab, Jawa, dan Madura saling membaur. Namun, pengecualian 
terjadi dengan pola sosialisasi antarteman yang berbeda jenis kelamin. Hal tersebut sesuai dengan ajaran islam yang mana tidak membeda-bedakan antarteman karena sesama umat islam adalah saudara. Namun, mereka secara tidak langsung juga diajari untuk mengetahui batas pergaulan apabila berbeda jenis kelamin. Budaya belajar mengembangkan pengelolaan kelas dengan adanya pola tempat duduk, kerja kelompok, dan perilaku inklusif guru dalam pembelajaran.

Internalisasi karakter nasionalisme harus dikembangkan Sekolah Dasar Islam Diponegoro karena kondisi keberagaman di sekolah tersebut sangat kentara. Keberagaman peserta didik di sana memberikan tantangan sekaligus peluang bagi pihak sekolah untuk menanamkan nasionalisme dan watak islamiyah dalam waktu bersamaan. Rekomendasi penelitian ini adalah perlu dilakukan penelitian secara kuantitatif berdasarkan instrumen mengenai variabel karakter nasionalis pada peserta didik di sekolah dasar. Dengan demikian, hasil tersebut dapat memprakirakan hasil yang menjangkau populasi lebih luas lagi. 


\section{DAFTAR PUSTAKA}

Açikalin, Mehmet. 2010. New Approaches for Teaching Social Studies: Multicultural and Global Education. Jurnal Elementary Education Online, Vol. 9, No. 3: 1226-1237.

Badan Pusat Statistik, Mengulik Data Suku di Indonesia. Diakses tanggal 14 Januari 2018. https://www.bps. go.id/news/2015/11/18/127/mengulik-data-suku-diindonesia.html.

Baig, Amina Bibi. 2015. Exploring the Contribution of Teaching and Learning Processes: Constructing Students' Gender Identity in an Early Years Classroom of a Government Girls Primary School in Pakistan. Jurnal Journal of International Women's Studies, Vol. 16, No.3: 1-15

Brandes, Tamar Hostovsky. 2012. Separate And Different: SingleSex Education And The Quest For Equality. Jurnal Israel Law Review, Vol.45, No.2: 235-266.

Chasiyah, Chadidjah, \& Legowo, Edy. 2009. Perkembangan Peserta Didik. Surakarta: Yuma Pustaka.

Chen, Shwu-Meei \& Lee, Young Ah. 2015. Dancing with Ethnic Identities: An Aboriginal Dance Club in a Taiwanese Middle School. Jurnal International Journal of Multicultural Education, Vol. 17, No. 2: 20-35.

Cihan, Tuğba \& Yildirim, Ali. 2014. Instructors' Perceptions of Social Interaction and Its Practical Reflections in Foreign Language Classes. Jurnal Elementary Education Online, Vol. 13, No. 3: 1033-1048.

Cozby, Paul C. 2009. Methods in Behavioral Research. Yogyakarta: Pustaka Pelajar.

Cresswell, John. 2015. Riset Pendidikan: Perencanaan, Pelaksanaan, dan Evaluasi Riset Kualitatif \& Kuantitatif. Diterjemahkan oleh Helly Prajitno Soetjipto dan Sri Mulyantini Soetjipto. Yogyakarta: Pustaka Pelajar.

D’hondt, Fanny; Eccles, Jacquelynne; van Houtte, Mieke; \& Stevens, Peter. 2016. Perceived Ethnic Discrimination by Teachers and Ethnic Minority Students' Academic 
Futility: Can Parents Prepare Their Youth for Better or for Worse? Jurnal J Youth Adolescence, Vol. 45:1075-1089.

Demir, Sezai \& Kaya, Alim. 2008. The Effect of Group Guidance

Program on the Social Acceptance Levels and Sociometric Status of Adolescents. Jurnal Elementary Education Online, Vol. 7, No. 1: 127-140.

Geven, Sara; Kalmijn, Matthijs; \& van Tubergen, Frank. 2016. The Ethnic Composition Of Schools And Students' Problem Behaviour In Four European Countries: The Role Of Friends. Jurnal Journal of Ethnic and Migration Studies, Vol. 42, No.9: 1473-1495.

Gibson, Robert L. \& Mitchell, Marianne H. 2011. Bimbingan dan Konseling. Yogyakarta: Pustaka Pelajar.

Hurlock, Elizabeth Bergner. 1980. Psikologi Perkembangan suatu Pendekatan Sepanjang Rentang Kehidupan (Ed). Diterjemahkan oleh Istiwidayanti dan Soedjarwo. Jakarta: Erlangga.

Irham, Muhammad \& Wiyani, Novan Ardy. 2014. Bimbingan \& Konseling: Teori dan Aplikasi di Sekolah Dasar. Yogyakarta: Ar-Ruzz Media.

Istihana, Istihana. 2015. Pengelolaan Kelas di Madrasah Ibtidaiyah. Jurnal Terampil: Jurnal Pendidikan dan Pembelajaran Dasar, Vol. 2, No. 2: 267-284

Juliardi, Budi. 2014. Ilmu Sosial Budaya Dasar. Bandung: Alfabeta. Kibui, Agnes; Mwaniki, Bernard; Gichuhi, Loise;Nyaga, Grace; Kahiga, Ruth W.; \& Ngesu. 2015. Multicultural Education as a Mechanism for Promoting Positive Ethnicity in Kenya. Jurnal International Journal of Scientific Research and Innovative Technology, Vol 2, No.3: 9-16.

Koonce, Glenn L. \& Mayo, Shauna S. 2013. Effects of Elementary School Students' Gender and Grade Level on Bullying. Jurnal American International Journal of Social Science, Vol. 2, No. 7: 16-25.

Korstjens, Irene \& Moser, Albine. 2018. Series: Practical Guidance to Qualitative Research. Part 4: Trustworthiness and Publishing. Jurnal European Journal of General Practice, Vol. 24, No. 1: 120-124. 
Li, Yaojun \& Heath, Anthony. 2017. The Socio-Economic Integration of Ethnic Minorities. Jurnal Social Inclusion, Vol. 5, No. 1: 1-4.

Lin, Yii-nii \& Chen, Yueh Hua. 2016. Primary School Teachers' Guidance Role and Competencies in Taiwan. Jurnal International Journal of Education and Social Science, Vol. 3, No.9: 76-80.

Mahfud, Choirul. 2014. Pendidikan Multikultural. Yogyakarta: Pustaka Pelajar.

Maknun, Djohar. 2013. Lingkungan Pembelajaran Sains yang Sehat, Aman, Nyaman dan Kondusif. Jurnal Scientiae Educatia, Vol. 2, No. 1: 34-51.

McDonald, Kristina L.; Malti, Tina; Killen, Melanie; \& Rubin, Kenneth H. 2014. Best Friends' Discussions of Social Dilemmas. Jurnal J Youth Adolescence, Vol. 43: 233-244.

Mikami, Amori Yee; Lerner, Matthew D; and Lun, Janetta. 2010. Social Context Influences on Children's Rejection by Their Peers. Child Development Perspectives, Vol. 4, No. 2: 123-130.

Mufid, Fathul. 2016. Spiritual Teaching dalam Membentuk Karakter Siswa di SMK Islam Tsamratul Huda Tahunan Jepara. Jurnal Edukasia: Jurnal Penelitian Pendidikan Islam, Vol. 11, No.2: 253-276.

Muhsinin. 2013. Model Pendidikan Karakter Berbasis Nilai-Nilai Islam untuk Membentuk Karakter Siswa yang Toleran. Jurnal Edukasia: Jurnal Penelitian Pendidikan Islam, Vol. 8, No. 2: 205-228.

Nasution, S. 1996. Metode Penelitian Naturalistik-Kualitatif. Bandung: Tarsito.

Nida, Fatma Laili Khoirun. 2013. Intervensi Teori Perkembangan Moral Lawrence Kohlberg dalam Dinamika Pendidikan Karakter. Jurnal Edukasia: Jurnal Penelitian Pendidikan Islam, Vol. 8, No.2: 271-290.

Putnam, JoAnne W.; Putnam, David E.; Jerome, Bernard; \& Jerome, Ramona. 2011. Cross-Cultural Collaboration for Locally Developed Indigenous Curriculum. Jurnal 
International Journal of Multicultural Education, Vol. 13, No.2: 1-18.

Riyani, Ely. 2011. Studi Kasus tentang Anak yang Memiliki Perilaku Sosial Negatif di Sekolah pada Siswa Kelas VI Sekolah Dasar Negeri I Sedayu Kabupaten Grobogan Tahun Pelajaran 2008/2009. Skripsi. Universitas Sebelas Maret Surakarta.

Russell, Jill; Berney, Lee; Stansfeld, Stephen; Lanz, Doris; Kerry, Sally; Chandola, Tarani; Bhui, Kamaldeep. 2016. The Role of Qualitative Research in Adding Value to a Randomised Controlled Trial: Lessons from a Pilot Study of a Guided E-Learning Intervention for Managers to Improve Employee Wellbeing and Reduce Sickness Absence. Trials, Vol. 17, No. 1: 396.

Saddhono, Kundharu \& Rohmadi, Muhammad. 2014. A Sociolinguistics Study on The Use of The Javanese Language in The Learning Process in Primary Schools in Surakarta, Central Java, Indonesia. International Education Studies, Vol. 7, No. 6: 25-30.

Sadik, Fatma; Çakan, Halil; \& Artut, Kazım. 2011. Analysis Of The Environmental Problems Pictures Of Children From Different Socio-Economical Level. Elementary Education Online, Vol. 10, No. 3: 1066-1080.

Setyaningsih, Rini \& Subiyantoro, Subiyantoro. 2017. Kebijakan Internalisasi Nilai Nilai Islam dalam Pembentukan Kultur Religius Mahasiswa. Jurnal Edukasia: Jurnal Penelitian Pendidikan Islam, Vol. 12, No.1: 57-86.

Subianto, Jito. 2013. Peran Keluarga, Sekolah, dan Masyarakat dalam Pembentukan Karakter Berkualitas. Jurnal Edukasia: Jurnal Penelitian Pendidikan Islam, Vol. 8, No.2: 331-354.

Sukmadinata, Nana Syaodih. 2011. Metode Penelitian Pendidikan. Bandung: Rosda.

Sulthon. 2016. Membangun Kesadaran Berperilaku Siswa Madrasah dengan Penguatan Nilai-Nilai Spiritual. Jurnal Edukasia: Jurnal Penelitian Pendidikan Islam, Vol. 11, No. 2: 399-420. 
Sunhaji. 2014. Konsep Manajemen Kelas dan Implikasinya dalam Pembelajaran. Jurnal Kependidikan, Vol. II, No. 2: 30-46.

Susetyo, Budi. 2010. Stereotip dan Relasi Antarkelompok. Yogyakarta: Graha Ilmu.

Sutirto, Tundjung W. 2000. Perwujudan Kesukubangsaan Kelompok Etnik Pendatang. Surakarta: Yayasan Pustaka Cakra.

Sutopo, B. 2006. Metodologi Penelitian Kualitatif: Dasar Teori dan Terapannya dalam Penelitian. Surakarta: UNS Press.

Suyadi. 2013. Strategi Pembelajaran Pendidikan Karakter. Bandung: Rosda.

Troop-Gordon, Wendy. 2015, The Role of the Classroom Teacher in the Lives of Children Victimized by Peers. Jurnal Child Dev Perspect, Vol. 9: 55-60.

Usman, Abdul Rani. 2009. Etnis Cina Perantauan di Aceh. Jakarta: Yayasan Obor Indonesia.

Vandello, Joseph. 2016. Do We Need a Psychology of Women in The Islamic World? Jurnal Sex Roles, No. 75: 623-629.

Ward, Jason K.; Comer, Unima; \& Stone, Suki. 2018. On Qualifying Qualitative Research: Emerging Perspectives and The "Deer" (Descriptive, Exploratory, Evolutionary, Repeat) Paradigm. Interchange, Vol. 49, No. 1: 133-146.

Wardani, Naniek Sulistya. 2015. Pengembangan Nilai-Nilai Budaya Sekolah Berkarakter. Jurnal Scholaria, Vol. 5, No. 3: 12-22.

Zafi, Ashif Az. 2017. Transformasi Budaya Melalui Lembaga Pendidikan (Pembudayaan dalam Pembentukan Karakter). Jurnal Sosiohumaniora, Vol. 3, No. 2: 105-112.

Zahroh, Lailatu. 2015. Pendekatan dalam Pengelolaan Kelas. Jurnal Tasyri, Vol. 22, No. 2: 175-189.

Zain, Hefni. 2013. Pengembangan Pendidikan Islam Multikultural Berbasis Manajemen Sumber Daya Manusia. Jurnal Tadrîs, Vol. 8, No. 1: 108-124.

Zamhari, Muhammad \& Masamah, Ulfa. 2016. Relevansi Metode Pembentukan Pendidikan Karakterdalamkitab Ta'limalMuta'allim terhadap Dunia Pendidikan Modern. Jurnal Edukasia: Jurnal Penelitian Pendidikan Islam, Vol.11, No.2: 421-442. 